\title{
THE LAST HUNDRED YEARS OF LAND USE HISTORY IN THE SOUTHERN PART OF VALDAI HILLS (EUROPEAN RUSSIA): RECONSTRUCTION BY POLLEN AND HISTORICAL DATA
}

\author{
Elena Novenko ${ }^{1,2 *}$, Pavel Shilov ${ }^{1}$, Dmitry Khitrov ${ }^{1}$, Daniil Kozlov ${ }^{1,3}$ \\ ${ }^{1}$ M.V. Lomonosov Moscow State University, Leninskie gory 1, 119991, Moscow, Russia; e-mail: lenanov@mail.ru \\ ${ }^{2}$ Institute of Geography, Russian Academy of Science, Staromonetny lane, 29, 119017, Moscow, Russia \\ ${ }^{3}$ V.V. Dokuchaev Soil Science Institute, Pyzhevsky lane 7/2, 119017, Moscow, Russia \\ * corresponding author
}

\begin{abstract}
The last one hundred years of land use history in the southern part of Valdai Hills (European Russia) were reconstructed on the base of high resolution pollen data from the peat monolith taken from the Central Forest State Reserve supplementing with historical records derived from maps of the General Land Survey of the $18^{\text {th }}$ and $19^{\text {th }}$ centuries and satellite images. According to the created age model provided by dating using radio-nuclides ${ }^{210} \mathrm{~Pb}$ and ${ }^{137} \mathrm{Cs}$, pollen data of the peat monolith allow us to reconstruct vegetation dynamics during the last one hundred years with high time resolution. The obtained data showed that, despite the location of the studied peatland in the center of the forest area and rather far away from possible croplands and hayfields, the pollen values of plants - anthropogenic indicators (Secale sereale, Centaurea cyanus, Plantago, Rumex, etc.) and micro-charcoal concentration are relatively high in the period since the beginning of the $20^{\text {th }}$ century to the $1970 \mathrm{~s}$, especially in the peat horizon formed in the $1950 \mathrm{~s}$. In the late $1970 \mathrm{~s}-$ the early 1980s when the pollen values of cereals gradually diminished in assemblages, the quantity of pollen of other anthropogenic indicators were also significantly reduced, which reflects the overall processes of the agriculture decline in the forest zone of the former USSR.
\end{abstract}

Key words: pollen analysis, peatland, land use history, the Central Forest State Reserve

Manuscript received 27 March 2017, accepted 6 November 2017

\section{INTRODUCTION}

Reconstructions of human influence on land use and vegetation is an essential issue in the modern palaeoecological studies. Since the Neolithic epoch, the arable farming, grazing, trampling, etc., were key factors influencing the spatial vegetation distribution (Taavitsainen et al., 1998; Vuorela et al., 2001; Kalis et al., 2003; Niinemets and Saarse, 2009; Gaillard et al., 2010; Kirleis et al., 2012). The most widely used approach for the qualitative interpretation of pollen assemblages in terms of past land-uses is the indicator species analyses (Behre, 1981; Vuorela, 1986; Ralska-Jasiewiczowa, 1977; Vorren, 1986; Koff and Punning, 2002; Zernitskaya and Mikhailov, 2009; Niinemets and Saarse, 2009; Josefsson et al., 2014; Saarse et al., 2010) as well as using relatively simple statistical models that relate percentages of arboreal and non-arboreal pollen to landscape openness (Frenzel et al., 1992; Rösch,
1992; Broström et al., 1998; Sugita et al., 1999; Mitchell, 2005). The further advantage in reconstructions of land cover changes is the application of sophisticated models, such as the Landscape Reconstruction Algorithm (Sugita 2007), which were used to reconstruct regional and local vegetation dynamics in different regions of Europe during the Holocene (Gaillard et al., 2008; Soepboer and Lotter, 2009; Nielsen et al., 2012; Hultberg et al., 2015).

A number of palaeoecological studies show the importance of adapting various historical data such as maps, chronicles, taxpayer lists, results of land survey and photographs together with proxy data from natural archives (Axelsson et al., 2002; Veski et al., 2005; Glaser and Riemann, 2009; Mazier et al., 2015) for land-use history reconstruction. The majority of these studies are focused on densely inhabited European regions where landscapes were strongly transformed by human activity over a hundred years. At the same time, in the area of the boreal forest 


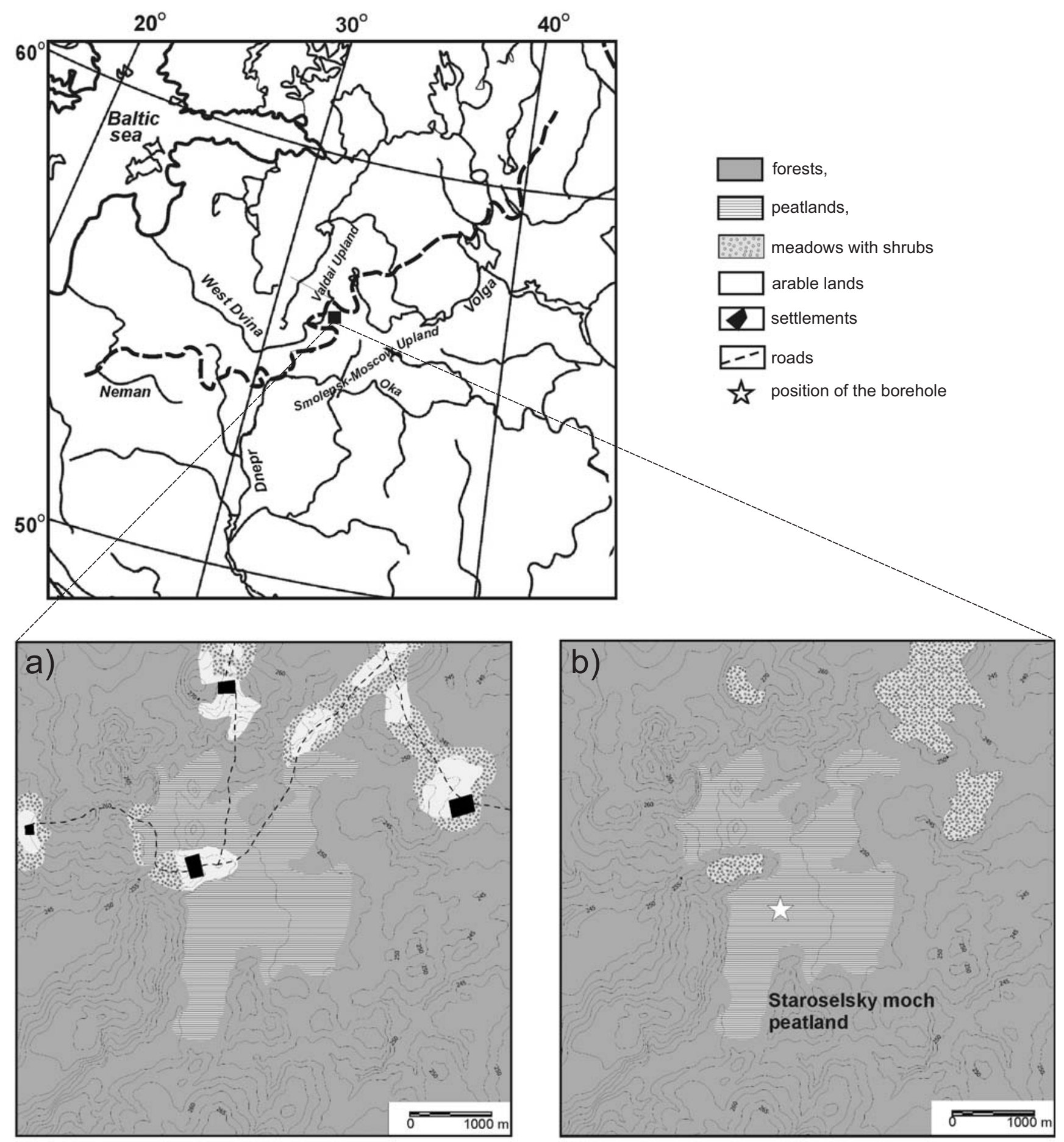

Fig. 1. Location of the study area and land use structure at the end of $19^{\text {th }}-$ beginning of the $20^{\text {th }}$ centuries (a) and at present (b).

with low human impact, records about human-vegetation relationship become scarce, the pollen evidence becomes weaker and more controversial (Hicks and Birks, 1996).

The area of the Central Forest State Natural Biosphere Reserve (CFSNBR) located in the southern part of the Valdai Hills has been chosen as a key region to study land use history in the central part of European Russia (Fig. 1). The place encompasses an extensive area of wetlands and low soil fertility, a situation far away from the main agri- cultural markets and industrial centers, a status as the state boundary during the relatively long period, weak developments of roads created difficulties for agricultural land use in the territories. As a result, human impact on landscapes has been very low for a long time (Novenko et al., 2009), which allowed us to study human activity in the relatively undisturbed forest region.

The Holocene history of vegetation and land use of the Valdai Hills was intensively investigated in a wide range of 
palaeogeographical studies (Karimov and Nosova, 1999; Minayeva et al., 2008; Novenko et al., 2009; Payne et al., 2016; Olchev et al., 2017). The present studies are based on high-resolution pollen sequences and historical maps for the last centuries. The aim of this paper is simultaneous analysis of recent land use in the Central Forest Biosphere Reserve by historical and pollen data and an identification of finescale human impact by changes in pollen assemblages.

Pollen data and age-depth model for peat core used in present studies have already been partly presented by Olchev et al. (2017) in the study focused on the analysis of relationships between pollen accumulation rates of woody taxa and selected herbaceous plants with local climate conditions. The complete pollen data have not been published.

\section{THE HISTORY OF LAND USE AND POPULATION OF THE TERRITORY}

Archeological findings within the CFSNBR are not yet known. In the historical chronicles of X-XII centuries, the area occupied by the Reserve nowadays was mentioned as a part of a vast, pathless forest, the massive "Okovsky Forest" (Karimov and Nosova, 1999). By this time, the territory, at least for some centuries, was settled by East Slavic tribes, expelling and assimilating the Ugro-Finnic population.

According to historical records, since the beginning of the XIV century and until the Russian-Polish War in 16541667 , the area of the Reserve during several long periods was located near the state border (Krom, 1995; Khitrov and Pakhunov, 2013). In this region the state matters of the Grand Principality of Lithuania, Muscovy and Poland collided and the territory repeatedly passed into the possession of one or the other state (Dumin, 2010). In the first decades of XVII century (so called "Time of Troubles"), marked by several natural disasters, civil war, Polish-Swedish intervention in Russia and political and socio-economic depression, the area of the CFSNBR was a place of severe warfare, and it was repeated in the 1650s, when Russia managed to finally move the border to the west. These led to the depopulation of the area and the decline of the economy and agriculture (Florja, 1998).

In XVIII century, European Russia was characterized by rapid growth of its economy and population. Maximum anthropogenic activity in the Tver' region occurred in the second half of the XVIII century (Borisenkov and Pasetski, 2002). The area of arable land and hayfields in the land-use structure reached its highest level. According to the economic notes to the General Land survey, the area of arable lands in 1780 reached 15\% (Karimov and Nosova, 1999). The density of the population grew up to 5 peoples $/ \mathrm{km}^{2}$, while in other parts of the Tver' region its value exceeded 10 people $/ \mathrm{km}^{2}$.

The potential limit for agricultural expansion was reached in the XIX century and after that the agriculture gradually declined. The arable land was replaced mainly by forests. The hard limitation of agriculture in the region due to an extensive area of wetlands and clayey poor soil was supplemented with a lack of hays and green fodder for cattle that supplied the main source of organic fertilizer for arable lands. As a result of natural conditions and historical processes, a structure of land use and settlements in the area of the CFSNBR was characterized by a complex pattern including vast areas of forests and wetlands interspersed with small inhabited and plowed lands.

\section{MATERIALS AND METHODS}

\section{Peat core sampling and age-depth model}

A peat monolith with a thickness of $65 \mathrm{~cm}$ was taken using a Wardenar' peat profile sampler during the field campaign in August 2013. The monolith consisted completely of low decomposed (7-10\%) cottongrass-sphagnum peat. The peat block was continuously sliced into samples with $1 \mathrm{~cm}$ thickness.

The age-depth models were based on radio-nuclides ${ }^{210} \mathrm{~Pb}$ (a constant rate of supply modeling and linear regression model) and a measurement of ${ }^{137} \mathrm{Cs}$ (Fig. 2) (Olchev et al., 2017). According to these data, the age of the lowermost sample of the peat monolith is about 1912 AD. Each sample within the uppermost $10 \mathrm{~cm}$ of peat profile corresponds to 1 year of sediment accumulation, and at the depths between $10 \mathrm{~cm}$ and $65 \mathrm{~cm}$ time resolution increased to several years.

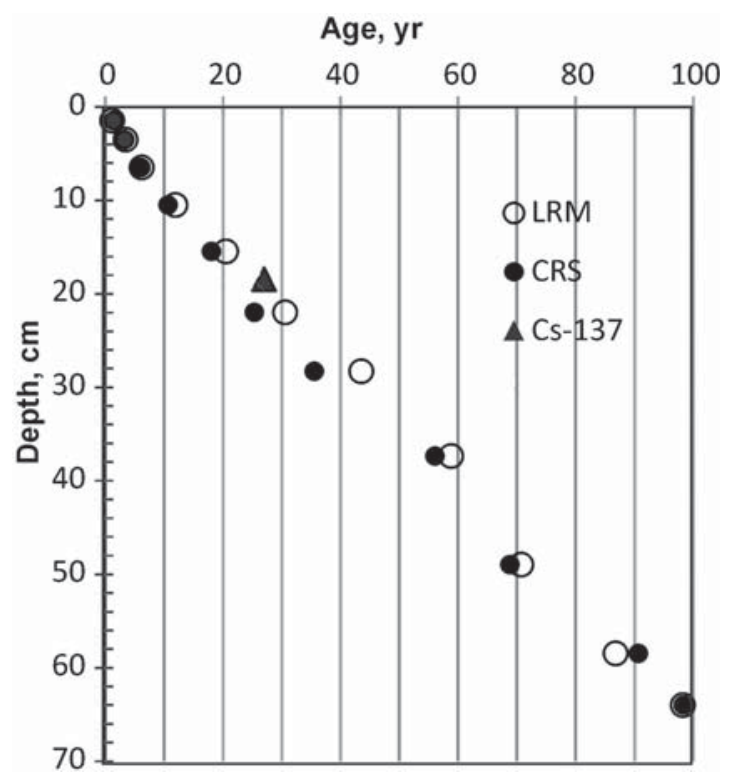

Fig. 2. Age-depth model of the peat monolith from the Staroselsky peat bog, calculated with Linear Regression Model (LRM) and Constant Rate of $\mathrm{Pb}-210$ Supply model (CRS); triangle indicates a maximum of ${ }^{137} \mathrm{Cs}$ activity, corresponding to the Chernobyl fallout (after Olchev et al., 2017).

\section{Pollen analysis}

Samples for pollen analysis were prepared using the pollen extraction procedure developed by Moore et al. 


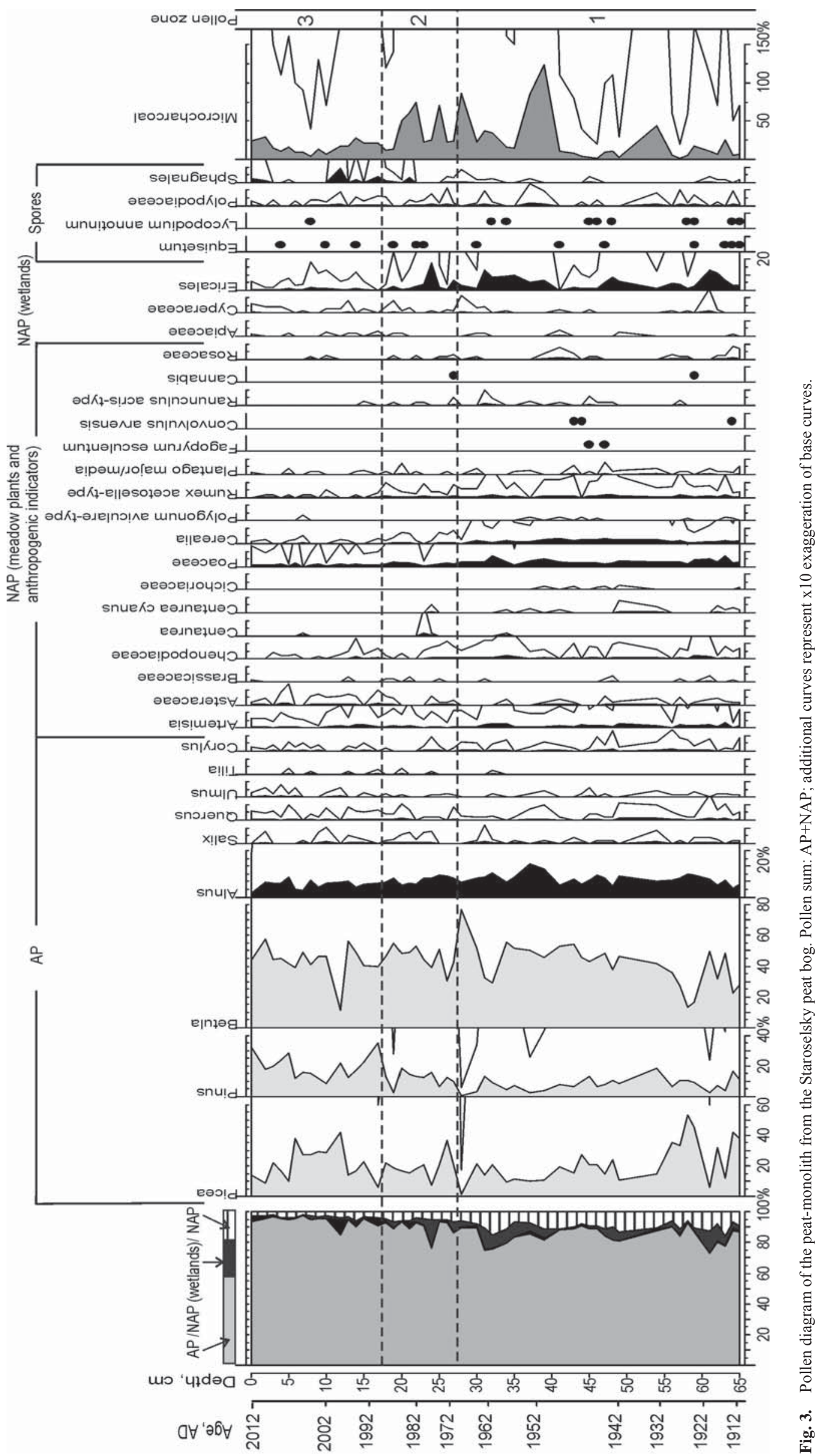


(1991). The treatment included heating for $10 \mathrm{~min}$ in $10 \%$ $\mathrm{KOH}$ to remove humic material, followed by acetolysis in a water bath for $5 \mathrm{~min}$ to dissolve the cellulose. Calculation of relative pollen frequency is based on the total terrestrial pollen sum, arboreal pollen (AP) plus non-arboreal pollen (NAP). Spores were excluded from the pollen sum. A minimum of 500 pollen grains per sample was counted (AP+NAP). Morphological determinations of pollen were carried out according to Reille (1992), Beug (2004) and the reference pollen collection of the Institute of Geography of the Russian Academy of Science. In order to determine pollen and charcoal concentrations, Lycopodium tablets were added to each sample (Stockmarr, 1971). Pollen diagrams were constructed using Tilia 2.0.2 and TGView programs (Grimm, 1990).

The determined herbaceous pollen taxa were grouped into two main categories (Fig. 3). The first group comprises land use indicator plants following Behre (1981), Berglund et al. (1986) and Koff and Punning (2002) that includes pollen indicating arable land (Cerealia, Fagopyrum esculentum, Cannabis, Centaurea cyanus, Convolvulus), ruderal communities (Chenopodiaceae, Artemisia, Plantago major/media, Polygonum aviculare-type and Rumex acetosella-type pollen) and pasture lands and meadows (Poaceae, Caryophyllaceae, Asteraceae, Cichoriaceae, Fabaceae, Rosaceae, Ranunculaceae, Rubiaceae). The second group is called NAP (wetlands) and includes pollen produced by local swamp vegetation. At the sampling point, they belong mainly to Apiaceae, Cyperaceae and Ericaceae families.

Microscopic charcoal concentrations were assessed following Clark's point-count methodology (Clark, 1982). At least 200 items (the sum of charcoal particles and Lycopodium spores) were counted (Finsinger and Tinner, 2005).

\section{Historical maps}

The reconstruction of the land use from the beginning of $20^{\text {th }}$ century is based on the data of the General land survey that is kept in Russian State Archive of Ancient Acts (http:// rgada.info/mende/rgada svg.php). These maps have a scale of 1:8400 and are allowed to describe the former land cover proportions with relatively high accuracy (Kusov, 2004). The old maps were digitized and georeferenced (Matasov, 2016) to fit topographic maps and remote sensing data that are available for the area of the CFSNBR. Stand delineation within the study area was digitized using MapInfo. Different land-use categories were reclassified and unified into four categories: forests, arable lands, meadows with shrubs and settlements. The roads connecting villages were also shown (Fig. 1a).

The map of the modern land cover (Fig. 1b) was compiled using topographic maps with a scale of 1:10000, remote sensing images as Spot 5 (2011), Landsat 5,7 (2000 and 2015, respectively). They are also georeferenced and combined in the integrated GIS.

\section{RESULTS}

\section{Pollen data}

Pollen assemblages of the peat monolith are characterized by a high amount of tree pollen (75-90\%); among them, Betula, Picea, Alnus and Pinus are abundant (Fig. 3). The amount of birch pollen in the monolith is very high up to $30-40 \%$, and it forms a noticeable peak at a depth of $27 \mathrm{~cm}$. The amount of Picea and Pinus pollen varied from $2-10 \%$ to $50-60 \%$ and $30-40 \%$, respectively. The proportion of Alnus pollen does not exceed 12\%. Pollen of broadleaf trees (Tilia, Ulmus, Quercus) occurred in small quantities (1-2\%); pollen of shrubs, such as Salix and Corylus, was rarely detected.

Pollen assemblages include a number of non-arboreal pollen; among them, Ericaceae, Artemisia and Poaceae are the most frequent. The total amount of spores does not exceed $10 \%$ of the entire peat monolith. Spores are represented mainly by Sphagnum and Polypodiaceae (5-7\%). A series of peaks of Sphagnum spore value (up to 10\%) and their concentration are recorded in the upper part of the peat monolith.

Pollen of anthropogenic indicators is a permanent component of pollen assemblages. According to changes of its amount pollen diagram was divided into 3 pollen assemblage zones corresponding to phases of intensity of human impact.

In pollen zone 1 (65-27 cm, 1912-1970 AD), pollen values of anthropogenic indicators varied between 15 and $25 \%$. Cerealia pollen forms a continuous curve, reaching $2-5 \%$ in the lower part of the pollen zone; pollen of cultivated plants such as Fagopyrum esculentum and Cannabis and weeds (Centaurea cyanus, Convolvulus arvensis) is recorded. Pollen of plants typical for ruderal communities (Chenopodiaceae, Artemisia, Plantago major/media, Polygonum aviculare-type, Ranunculus acris-type and Rumex acetosella-type pollen) and ruderal and pasture lands and meadows (Poaceae, Caryophyllaceae, Asteraceae, Cichoriaceae, Fabaceae, Rosaceae) are frequent (Fig. 3). The highest pollen concentration of Cerealia and ruderal plants is recorded in the depth 42-35 cm (1947-1955 AD).

In pollen zone 2 (27-17 cm, 1970-1989 AD), a clear decrease in pollen percentages and concentrations of cereals and ruderal vegetation is detected. The share of Cerealia pollen decreased to $1-1.5 \%$. In the uppermost $17 \mathrm{~cm}$ (pollen zone 3, 1989-2012 AD) of the peat monolith, the share of plants-anthropogenic indicators decreased to $5-7 \%$; pollen concentration of these taxa is low. The proportion of Cerealia did not exceed $0.5 \%$.

The whole peat monolith comprises a high amount of micro-charcoal particles. An increase of their proportion is recorded for the depth 55-50 cm, 1930-1940 AD (about 50\% in comparison to the sum of AP+NAP). Micro-charcoal particles are the most abundant in the interval 40-20 cm (19471985 AD), reaching their maximum values (up to $150 \%$ ). In the upper part of peat monolith, both the proportion and concentration of charcoal are drastically decreased. 


\section{Historical data}

The reconstructions of land use at the end of the XIX centuries show that the study area in that time was inhabited and cultivated (Fig. 1a). There are four villages surrounded by arable lands and meadows; these covered $5 \%$ and $4 \%$ of the area, respectively. However, the human impact was relatively low. Forests occupied about $82 \%$ of the territory. The Staroselsky peat bog is shown as a forest in the map of the General land survey. Obviously, the mire areas were covered by pine woodland.

Analysis of the recent map of modern land cover demonstrates that the forest area is increased to $89 \%$ and peatlands cover $13 \%$ (Fig. 1b). Villages are abandoned, and roads disappear. The arable lands transformed to meadows with shrubs (5\%). During our field studies, we visited the places of former settlements and did not find any signs of dwellings or gardens with the exception of the village of Staroselie where one partly destroyed house still existed. According to interviews with the local people, arable lands were cultivated until 1980s, but the total decline of the economy and agriculture took place after 1990s.

\section{DISCUSSIONS}

High-resolution pollen data from the peat monolith from the Staroselsky Moch peat bog and obtained historical data allow us to describe land use changes in the study area during the last 100 years. According to the intensity of human impact on the study area, three time intervals were determined (Fig. 4):

1) 1912 - the $1970 \mathrm{~s} \mathrm{AD}$, moderate human impact (settlements, arable lands and cattle breeding);

2) the 1970s - the 1990s AD, low human impact (decrease in agricultural activity in the area);

3) the $1990 \mathrm{~s}-2012 \mathrm{AD}$, no direct human impact (abandonment of villages).

The first rather long periods were divided into three subphases; these corresponded to the time interval before World War II (1a), the period during the war (1b) and economic recovery after it (1c, Fig. 4).

These phases were distinguished on the basis of AP/ NAP ratio (Frenzel et al., 1992; Rösch, 1992), indicator species (Behre, 1981) and changes in the composition of herbaceous pollen (Koff and Punning, 2002). The commonly used criteria such as proportion of Picea, broadleaved trees and Betula pollen in assemblages (Ralska-Jasiewiczowa, 1977) could not be applied for our study. As indicated in the study provided by Olchev et al (2017), variations in Picea and Betula pollen values with duration from several years to a decade in the CFSNBR during the last 100 years were caused by changes in pollen productivity of trees mainly due to climatic reasons.

At the beginning of the XX century, the study area was relatively densely inhabited. In spite of unfavorable conditions for agriculture (Novenko et al., 2009) the territory was actively used for farming and grazing. The Russian
Revolution in 1917 eventually led to the formation of the Soviet Union in 1922, in turn triggering a phase of collectivization and industrialization in agriculture with the goal of increasing agricultural production. The share of cereals in pollen assemblages of that time reached $5 \%$, pollen of probably cultivated plants - Fagopyrum esculentum and Cannabis sativa - was recorded, designating an existence of arable lands adjacent to the peat bog (Koff and Punning, 2002). According to the historical data (Fig. 1a), arable lands occupied $5 \%$ of the studied area and were located around villages. The presence of typical weed plants in pollen assemblages, such as Convolvulus arvensis and Centaurea cyanus, is typical for permanent farm fields (Vuorela et al., 2001; Zernitskaya and Mikhailov, 2009). The reliable diagnostic sign of human impact on vegetation in studied pollen assemblages is the appearance of species indicating trampling or grazing (Berlund et al., 1986): Polygonum aviculare, Plantago major/media, pasture lands (Rumex acetosella, Ranunculus acris), Cichoriaceae, Rosaceae and plants of ruderal communities, such as Artemisia, Asteraceae and Chenopodiaceae. It should be noted that, in the flora of the CFSNBR in the Chenopodiaceae family, only Chenopodium album and Ch. rubrum, the ruderal species, are present (Minyaev and Konechnaya, 1976). A relatively high amount of herbaceous plants with wide ecological requirements but in forest vegetation zone mainly typical for meadow communities such as Poaceae, Rosaceae, Brassicaceae, suggested the existence of meadows and hayfield, the share of which in the early $20^{\text {th }}$ century was 4\%. An increase of micro-charcoal concentration in peat formed in 1930-1940s AD, obviously, reflected the beginning of brown coal mining of the Moscow coal basin in the vicinity of the town of Nelidovo, located about 40 $\mathrm{km}$ south of the CFSNBR, and use of brown coal as a fuel.

World War II (1941-1945 AD) led to a drastic disruption of the economy and agriculture in the country, followed by the need to restore the economy after the war. In the peat formed during the first decade after World War II, pollen values of anthropogenic indicators reached the maximum for the entire period (Fig. 4). The input of coal particles decreased significantly during the war, but at the beginning of the 1950s its concentration grew in order of magnitude.

Agricultural land use in the former Soviet Union expanded in the 1950s and 1960s; during the next period (19651980) the government policy to agricultural intensification and concentration led to the abandonment of marginal areas like the Central Forest State Reserve (Blinnikov, 2011). The share of anthropogenic indicators in pollen assemblages and primarily that of Cerealia has gradually decreased since the 1970s. The local population either engaged in forestry in non-protected territories around the CFSNBR or moved to work in the brown coal mines; however, agriculture in the vicinity of the settlements was still maintained.

The breakup of the Soviet Union in 1991 and the subsequent transition to market economy affected agriculture in the region markedly. Formerly guaranteed markets and state subsidies disappeared, agricultural institutions were overhauled, and agricultural land was privatized (Ioffe and 


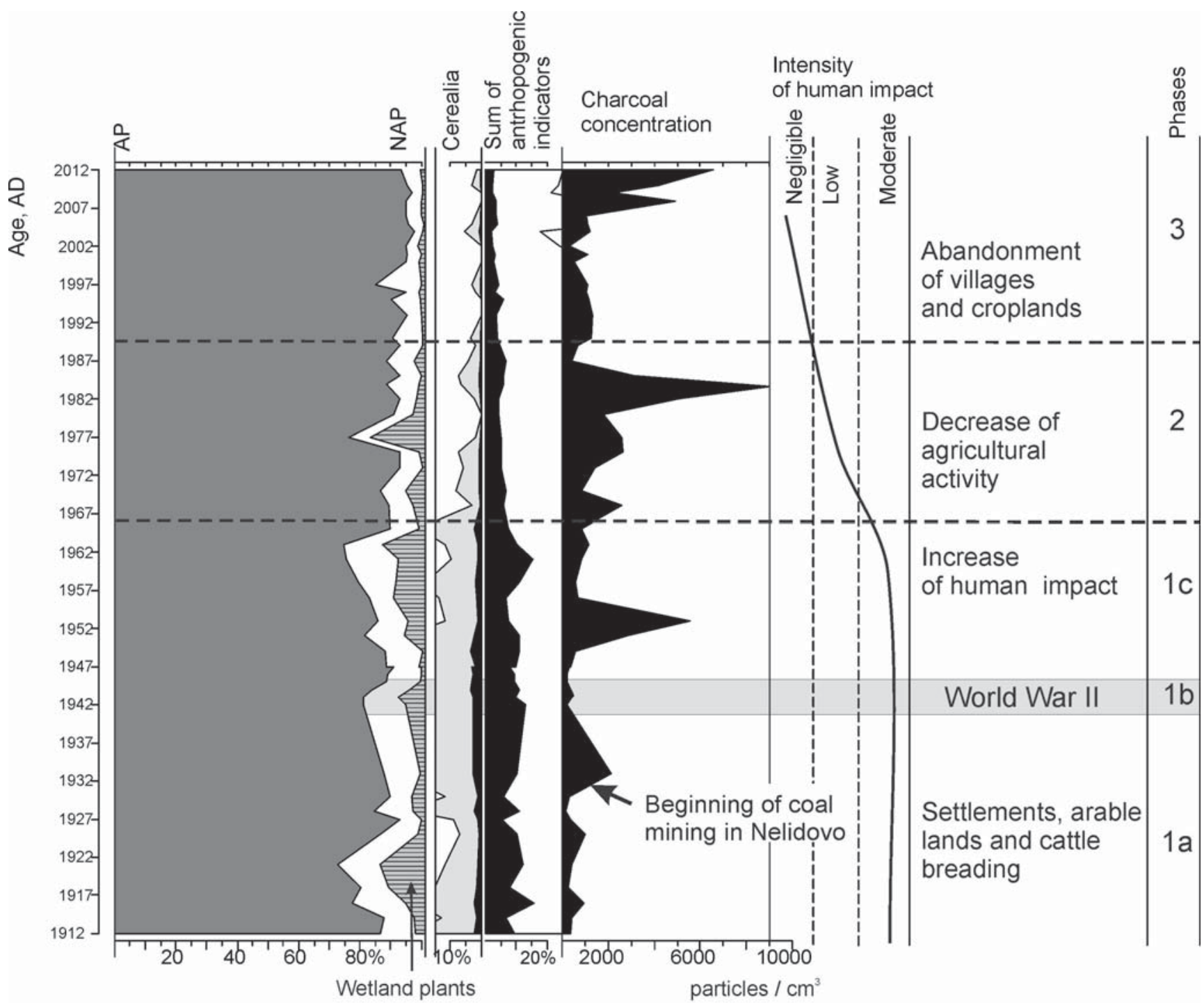

Fig. 4. Summary of the results of pollen analysis of the peat-monolith from the Staroselsky peat bog and phases of the intensity of human impact on the surrounding area. Cerealia pollen curve is shown with additional counter represents x10 exaggeration of the base curve.

Nefedova, 2004; Lerman et al., 2004; Kuemmerle et al., 2015), together resulting in drastic production declines and widespread agricultural abandonment (Prishchepov et al., 2012; Schierhorn et al., 2013). While some of the abandoned lands in European Russia were recultivated after 2000 AD due to growing support for agriculture from several government programs, much of the former agricultural land remains abandoned and is gradually returning to forest (Hansen et al., 2013; Sieber et al., 2013; Kuemmerle et al., 2015). Nowadays, agriculture in the region of the CFSNBR located far from main roads and industrial centers is economically unprofitable. At the beginning of the $21^{\text {st }}$ century, most of the villages were abandoned, the total population fell by $5-10$ times. Of the 180 villages in the area included in the modern boundaries of the CFSNBR and adjacent territories shown on the map at the early $20^{\text {th }}$ century as inhabited, only 30 are still existing.

The modern land cover of the study area is represented by forest, peatland and meadows with shrubs (Fig. 1b).
Since the 1990s the share of non-arboreal pollen in assemblages has become low. Pollen of cultivated plants, with the exception of cereals, and weed disappeared completely. The Cerealia pollen values (mainly wind pollinated Secale cereale) do not exceed $0.5 \%$. According to Koff and Punning (2002), cereal pollen less than $2 \%$ could be assumed as regional background pollen influx. The decrease of the farm economy in the region led to a change in water balance that could be a reason for the active wetland development marked by high peaks of Sphagnum spores in the upper part of the peat profile. Moreover, intensive forest paludification and wetland growth might be induced due to climate warming and increase of humidity during the $20^{\text {th }}$ century (Desherevskaya et al., 2010).

The noticeable decrease in micro-charcoal values in peat indicates a decline of the brown coal industry in the region due to the economic crisis in the country. In the early 1990s, coal mines were closed and flooded by water, and today there are no active brown coal mines in the region. 
Micro-charcoal particles contained in the upper horizons of peat probably came from old anthracite dumps which are abundant around the town of Nelidovo.

\section{CONCLUSIONS}

The new pollen and historical records from the Central Forest State Reserve provide important data about vegetation development and land use of the study area. According to obtained results, during the last 100 years, the area of the CFSNBR was covered by forests and human activity was low; the share of cultivated lands did not exceed $5 \%$. The obtained data showed that despite the location of the studied peatland in the center of the forest area and rather far away from possible croplands and hayfields, the pollen values of plants - anthropogenic indicators (Secale sereale, Centaurea cyanus, Plantago, Rumex, etc) - and micro-charcoal concentrations were relatively high in the period when the study area was inhabited and cultivated and significantly diminished since the 1990s when the area became abandoned.

The pollen data demonstrated that pollen assemblages are able to reflect this weak human impact on vegetation, and even fine-scale land use changes are traced in the composition of pollen spectra. The decadal-scale vegetation response to human-induced forcing agrees with historical maps and documents and can be used to reconstruct past landscapes prior to the time for which solid historical data are available. The obtained results show that pollen data could be successfully applied for reconstructions of interrelationships between prehistoric groups of people and the environment in the initial phases of human settlements.

\section{Acknowledgement}

This study was supported by a grant from the Russian Science Foundation (Grant 16-17-10045).

\section{REFERENCES}

Axelsson, A.-L., Östlund, L., Hellberg, E., 2002. Changes in mixed deciduous forests of boreal Sweden 1866-1999 based on interpretation of historical records. Landscape Ecology 17, 403-418.

Behre, K.-E., 1981. The interpretation of antropogenic indicators in pollen diagrams. Pollen et Spores 23, 225-245.

Berlund, B.E., Persson, T., Emanuelsson, U., Persson, S., 1986. Pollen/ vegetation relationships in grazed and mowed plant communities of south Sweden. In: Behre, K-E. (Ed.) Anthropogenic indicators in pollen diagrams, 37-51. Balkema, Rotterdam.

Beug, H-J., 2004. Leitfaden der Pollenbestimmung für Mitteleuropa und angrenzende Gebiete. 542 pp. Verlag Friedrich Pfeil, Munich.

Blinnikov, M.S., 2011. A Geography of Russia and Its Neighbors. Guilford Press, New York.

Borisenkov, E.P., Pasetski, V.M., 2002. Chronicle of unusual natural phenomena for 2.5 millennia. 536 pp. Gidrometeoisdat, St. Petersburg (in Russian).

Broström, A., Gaillard, M.-J., Ihse, M., Odgaard, B., 1998. Pollenlandscape relationships in modern analogues of ancient cultural landscapes in southern Sweden - a first step towards quantification of vegetation openness in the past. Vegetation History Archaeobotany 7, 189-201.

Clark, R.L., 1982 Point count estimation of charcoal in pollen preparations and thin sections of sediments. Pollen et Spores 24, 523-535.

Desherevskaya, O., Kurbatova, J., Olchev, A., 2010. Climatic conditions of the south part of Valday Hills, Russia, and their projected changes during the 21st century. Open Geography Journal 3, 73-79.

Dumin, S.V., 2010. Smolensk voivodeship as a part of Poland in 16181654. In: Fedorov, B.G. (Ed.) Smolensk gentry, 81-110. "Svitok", Smolemsk (in Russian).

Finsinger, W., Tinner, W., 2005. Minimum count sums for charcoal-concentration estimates in pollen slides: reliability and potential errors. The Holocene 15, 293-297.

Florja, B.N. 1998. The state of orthodox christians of Smolensk region as a part of Poland ( $20^{\text {th }}-40^{\text {th }}$ years of XVII century). Revue des études slaves 70 (2), 333-345 (in Russian).

Frenzel, B., Rosch, L, Gläser, B., 1992. Evaluation of land surfaces cleared from forest by prehistoric man in early Neolithic times and the time of migrating German tribes. Paläoklimaforschung Palaeoclimate Research 8, 83-91. Fischer, Stuttgart.

Gaillard, M.-J., Sugita, S., Bunting, J., Dearing, J., Bittmann, F., 2008. Human impact on terrestrial ecosystems, pollen calibration and quantitative reconstruction of past land-cover. Vegetation History Archaeobotany 17, 415-418.

Gaillard, M.-J., Sugita, S., Mazier, F., 2010. Holocene land-cover reconstructions for studies on land cover-climate feedbacks. Climate in the Past 6, 483-499.

Glaser, R., Riemann, D., 2009. A thousand-year record of temperature variations for Germany and Central Europe based on documentary data. Journal of Quaternary Science 24, 437-449.

Grimm, E.C. 1990. TILIA and TILIA*GRAPH.PC spreadsheet and graphics software for pollen data. INQUA, Working Group on DataHandling Methods. Newsletter 4, 5-7.

Hansen, M.C., Potapov, P.V., Moore, R., 2013. High-resolution global maps of $21^{\text {st }}$ century forest cover change. Science $342,850-853$.

Hicks, S., Birks, H.J.B., 1996. Numerical analysis of modern and fossil pollen spectra as a tool for elucidating the nature of fine-scale human activities in boreal areas. Vegetation History Archaeobotany 5, 257-272.

Hultberg, T., Gaillard, M.-J., Grundmann, B., Lindbladh, M., 2015. Reconstruction of past landscape openness using the Landscape Reconstruction Algorithm (LRA) applied on three local pollen sites in a southern Swedish biodiversity hotspot. Vegetation History Archaeobotany 24, 253-266.

Ioffe, G., Nefedova, T., 2004. Marginal farmland in European Russia. Eurasian Geography and Economics 45, 45-59.

Josefsson, T., Ramqvist, P.H., Hörnberg, G., 2014. The history of early cereal cultivation in northernmost Fennoscandia as indicated by palynological research. Vegetation History Archaeobotany 23, 821-840.

Kalis, A.J., Merkt, J., Wunderlich, J., 2003. Environmental changes during the Holocene climatic optimum in central Europe - human impact and natural causes. Quaternary Science Reviews 22, 33-79.

Karimov, A.E., Nosova, M.B., 1999. Land use and its influence on the nature of the Central Forest Reserve (the end of $16^{\text {th }}$ - the beginning of the $20^{\text {th }}$ century). In: Smirnova O.V., Shaposhnikov, E.S. (Eds) Forest successions in protected areas of Russia and problems of biodiversity conservations, 299-310. Russian Botanical Society, St. Petersburg (in Russian).

Khitrov, D., Pakhunov, S., 2013. Provincial reform of 1775 in the Smolensk gubernia: how the system of administrative-territorial division was formed. Rodina 9, 80-83 (in Russian).

Kirleis, W., Klooß, S., Kroll, H., Müller, J., 2012. Crop growing and gathering in the northern German Neolithic: a review supplement- 
ed by new results. Vegetation History and Archaeobotany 21 (3), 221-242.

Koff, T., Punning, J.-M., 2002. The last hundred years of land-use in Estonia as inferred from pollen records. Annales Botanici Fennici 39, 213-224.

Krom, M.M., 1995. Between Russia and Lithuania. Western Russian lands in the system of Lithuanian-Russian relationship at the end of XV - the first third of XVI centuries. $92 \mathrm{pp}$. Archeological center-press, Moscow (in Russian)

Kuemmerle, T., Kaplan, J.O., Prishchepov, A.V., Rylsky, I., Chaskovsky, O., Tikunov, V.S., Müller, D., 2015. Forest transitions in Eastern Europe and their effects on carbon budgets. Global Change Biology 21, 3049-3061.

Kusov, V.S. 2004. Lands of Moscow gubernia in the XVIII century. 400 pp. "Moscovia", Moscow (in Russian).

Lerman, Z, Csaki, C., Feder, G., 2004. Evolving farm structures and land-use patterns in former socialist countries. Quarterly Journal of International Agriculture 43, 309-335.

Matasov, V.M. 2016. Methodological aspects of the analysis of the land use structure in the Kasimov uezd at the end of the XVIII century. Geodesy and cartography 3, 59-64 (in Russian).

Mazier, F., Broström, A., Bragée, P., Fredh, D., Stenberg, L., Thiere, G., Sugita, S., Hammarlund, D., 2015. Two hundred years of landuse change in the South Swedish Uplands: comparison of historical map-based estimates with a pollen-based reconstruction using the landscape reconstruction algorithm. Vegetation History and Archaeobotany 24, 555-570.

Minayeva, T.Yu., Trofimov, S.Ya., Dorofeyeva, E.I., Chichagova, O.A., Sirin, A.A., Glushkov, I.V., Mikhailov, N.D., Kromer, B., 2008. Carbon accumulation in soils of forest and bog ecosystems of southern Valdai in the Holocene. Biology Bulletin 35 (5), 524 532.

Minyaev, N.A., Konechnaya, G.Y., 1976. Flora of the Central Forest State Reserve. 104 pp. Nauka, Moscow (in Russian).

Mitchell, F.J.G., 2005. How open were European primeval forests? Hypothesis testing using palaeoecological data. Journal of Ecology 93, 168-177.

Moore, P.D., Webb, J.A., Collinson, M.E., 1991. Pollen Analysis. 216 pp. Blackwell, Oxford.

Nielsen, A.B., Giesecke, T., Theuerkauf, M., 2012. Quantitative reconstructions of changes in regional openness in north-central Europe reveal new insights into old questions. Quaternary Science Reviews 47, 131-149.

Niinemets, E., Saarse, L., 2009. Holocene vegetation and land-use dynamics of south-eastern Estonia. Quaternary International 207, 104-116.

Novenko, E.Yu., Volkova, E.M., Nosova, M.B., Zuganova, I.S., 2009. Late Glacial and Holocene landscape dynamics in the southern taiga zone of East European Plain according to pollen and macrofossil records from the Central Forest State Reserve (Valdai Hills, Russia). Quaternary International 207, 93-103.

Olchev, A., Novenko, E., Popov, V., Pampura, T., Meili, M., 2017. Evidence of temperature and precipitation change over the past 100 years in a high-resolution pollen record from the boreal forest of Central European Russia. The Holocene 27, 740-751.

Payne, R.J., Malysheva, E., Tsyganov, A., Pampura, T., Novenko, E., Volkova, E., Babeshko, K., Mazei, Yu., 2016. A multi-proxy record of Holocene environmental change, peatland development and carbon accumulation from Staroselsky Moch peatland, Russia. The Holocene 26, 314-326.

Prishchepov, A.V., Radeloff, V.C., Baumann, M., Kuemmerle, T., Müller, D., 2012. Effects of institutional changes on land use: agricultural land abandonment during the transition from state-command to market-driven economies in post-Soviet Eastern Europe. Environment Research Letters 7: 24021.

Ralska-Jasiewiczowa, M., 1977. Impact of prehistoric man on natural vegetation recorded in pollen diagrams from different regions of Poland. Folia Quaternaria 49, 5-91.

Reille, M. 1992. Pollen et spores d'Europe et d'Afrique du Nord. 331 pp. Laboratoire de Botanique Historique et Palynologie, Marseille.

Rösch, M. 1992. Human impact as registered in the pollen record: some results from the western Lake Constance region, Southern Germany. Vegetation History Archaeobotany 1, 101109.

Saarse, L., Niinemets, E., Poska, A., Veski, S. 2010. Is there a relationship between crop farming and the Alnus decline in the eastern Baltic region? Vegetation History Archaeobotany 19, 17-28.

Schierhorn, F., Müller, D., Beringer, T., Prishchepov, A.V., Kuemmerle, T., Balmann, A., 2013. Post-Soviet cropland abandonment and carbon sequestration in European Russia, Ukraine, and Belarus. Global Biogeochemical Cycles 27, 1175-1185.

Sieber, A., Kuemmerle, T., Prishchepov, A.V., Wendland K.J., Baumann M., Radeloff V.C., Baskin L.M., Hostert P., 2013. Landsat-based mapping of post-Soviet land-use change to assess the effectiveness of the Oksky and Mordovsky protected areas in European Russia. Remote Sensing of Environment 133, 38-51.

Soepboer, W., Lotter, A.F., 2009. Estimating past vegetation openness using pollen-vegetation relationships: A modelling approach. Review of Palaeobotany and Palynology 153, 102-107.

Stockmarr, J., 1971. Tablets with spores used in absolute pollen analysis. Pollen et Spores 13, 615-621.

Sugita, S., 2007. Theory of quantitative reconstruction of vegetation. I. Pollen from large sites REVEALS regional vegetation. The Holocene 17, 229-241.

Sugita, S., Gaillard, M.J., Broström, A., 1999. Landscape openness and pollen records: A simulation approach. The Holocene 9, 409-421.

Taavitsainen, J.-P., Simola, H., Gronlund, E., 1998. Cultivation history beyond the periphery: early agriculture in the North European boreal forest. Journal of World Prehistory 12, 199-253.

Veski, S., Koppel, K., Poska, A., 2005. Integrated palaeoecological and historical data in the service of fine-resolution land use and ecological change assessment during the last 1000 years in Rõuge, southern Estonia: Land use and ecological change assessment in southern Estonia. Journal of Biogeography 32, 1473-1488.

Vorren, K.-D., 1986. The impact of early agriculture on the vegetation of Nothern Norway. A discussion of antropogenic indicators in pollen diagrams. In: Behre, K.-E. (Ed.) Anthropogenic indicators in pollen diagrams, 1-18. Balkema, Rotterdam.

Vuorela, I., 1986. Palynological and historical evidence of slash-andburn cultivation in South Finland. In: Behre, K.-E. (Ed.) Anthropogenic indicators in pollen diagrams, 53-64. Balkema, Rotterdam.

Vuorela, I., Saarnisto, M., Lempiäinen, T., Taavitsainen, J.P., 2001. Stone Age to recent land-use history at Pegrama, northern Lake Onega, Russian Karelia. Vegetation History Archaeobotany 10, 121-138.

Zernitskaya, V., Mikhailov, N., 2009. Evidence of early farming in the Holocene pollen spectra of Belarus. Quaternary International 203, 91-104. 